\title{
Correlation Between Hemoglobin Levels and the Prognosis of First-Line Chemotherapy in Patients with Advanced Gastric Cancer
}

This article was published in the following Dove Press journal: Cancer Management and Research

\author{
Qing Wei* \\ Xing Yuan (D) \\ Qi Xu \\ Jingjing $\mathrm{Li}$ \\ Lei Chen \\ Jieer Ying
}

Cancer Hospital of the University of Chinese Academy of Sciences (Zhejiang Cancer Hospital); Institute of Cancer and Basic Medicine (ICBM), Chinese Academy of Sciences, Hangzhou 310022, People's Republic of China

*These authors contributed equally to this work
Correspondence: Jieer Ying

Cancer Hospital of the University of Chinese Academy of Sciences (Zhejiang

Cancer Hospital); Institute of Cancer and Basic Medicine (ICBM), Chinese Academy of Sciences, Hangzhou 310022, People's Republic of China

Email jieerying@aliyun.com
Background: This retrospective study evaluated the prognostic significance of hemoglobin $(\mathrm{Hb})$ levels in patients (pts) with unresectable locally advanced or metastatic gastric cancer who have not previously received chemotherapy.

Patients and Methods: We screened 249 pts with advanced gastric cancer, who were categorized into four groups, namely, non-anemia (normal $\mathrm{Hb}$ levels), mild (10 g/dl to normal), moderate $(8-10 \mathrm{~g} / \mathrm{dl})$, and severe anemia groups $(<8 \mathrm{~g} / \mathrm{dl})$, to study the prognostic significance of $\mathrm{Hb}$ levels. We also examined the correlation between changes in $\mathrm{Hb}$ levels and treatment effects via imaging during the treatment course.

Results: The objective response rate (ORR) was $47.4 \%$ for pts with anemia versus $43.4 \%$ for pts without anemia $(P=0.536)$. Hemoglobin levels were reduced by $0.51 \pm 1.86$ and 1.93 $\pm 1.33 \mathrm{~g} / \mathrm{dl}$ after chemotherapy versus before chemotherapy in the disease control group and progressive groups, respectively $(\mathrm{P}=0.002)$. The median progression-free survival (mPFS) of first-line chemotherapy in all pts was 6.3 months. Specifically, the mPFS was 5.7 months in pts with severe anemia, compared with 6.4 months for pts with non-severe anemia $(\mathrm{Hb} \geq 8 \mathrm{~g} /$ dl). The median overall survival (mOS) of all pts was 14.0 months. In particular, the mOS was 15.0 months for pts with non-anemia and mild anemia $(\mathrm{Hb} \geq 10 \mathrm{~g} / \mathrm{dl})$ versus 11.5 months for pts with moderate or severe anemia. In multivariate analysis, ascites and decreased $\mathrm{Hb}$ post-chemotherapy were identified as independent prognostic indicators for PFS and OS.

Conclusion: Our findings indicate that $\mathrm{Hb}$ levels are associated with the prognosis in the first-line chemotherapy for pts with advanced gastric cancer. Pts with progressive disease experience a larger decrease in $\mathrm{Hb}$ levels, and those with baseline $\mathrm{Hb}$ levels $\geq 10 \mathrm{~g} / \mathrm{dl}$ experience longer OS.

Keywords: anemic, hemoglobin, gastric cancer, prognosis

\section{Introduction}

Gastric cancer is the fifth most common malignancy globally, and half of all cases occur in Eastern Asia (mainly in China). ${ }^{1}$ Patients with gastric cancer are typically diagnosed with stage IV disease, precluding surgical treatment. ${ }^{2}$ Anemia is one of the common concomitant diseases of advanced gastric cancer (AGC). ${ }^{3}$ The cause is multifactorial, ${ }^{4}$ including hemorrhage, hemolysis, nutritional deficiencies, renal insufficiency, hormonal dysfunction, and other factors. Malignant tumors can cause or aggravate anemia via several mechanisms. In particular, cancer cells destroy hematopoietic cells and inhibit hematopoietic function by infiltrating bone marrow infiltration and reducing peripheral hemoglobin $(\mathrm{Hb})$ levels. Blood loss 
caused by tumor sites can further aggravate anemia., Other reasons include immune-mediated antibody hemolysis and changes in blood clotting capacity. ${ }^{7}$

Low $\mathrm{Hb}$ content is one of the factors affecting the outcomes of pts with AGC. A series of studies confirmed that anemia worsens the prognosis of gastric cancer. ${ }^{8,9}$ However, some studies found no correlation between anemia and the outcomes of gastric cancer, ${ }^{10,11}$ and thus, the impact of $\mathrm{Hb}$ levels on prognosis in pts with AGC receiving first-line chemotherapy remains unclear.

To resolve this issue, our study evaluated the prognostic significance of $\mathrm{Hb}$ levels in pts with AGC who have not previously received chemotherapy. Additionally, we explored the relationship between the change of hemoglobin levels following chemotherapy and efficacy in pts with AGC to provide some evidence for improving the prognosis of such pts.

\section{Patients and Methods Study Population}

This study was approved by the Ethics Committee of Zhejiang Cancer Hospital and was conducted according to the principles of the Declaration of Helsinki. As this retrospective study did not harm the rights and health of patients and protected their privacy and personal information, the ethics committee waived the requirement to obtain informed consent. In this single-institution retrospective study, we collected data of 397 pts with unresectable locally advanced or metastatic gastric adenocarcinoma who received first-line chemotherapy at Zhejiang Cancer Hospital between 2006 and 2017 (Figure 1). All pts received at least two cycles of chemotherapy, and measurable lesions were confirmed via imaging. Two hundred and forty-nine consecutive gastric cancer patients were further analyzed. Clinical parameters, including age, gender, Eastern Cooperative Oncology Group performance status, anatomic tumor location, stage of differentiation, Lauren classification, Her-2 expression, liver metastasis, lymph node metastasis, presence of ascites, and initial platelet counts were obtained by reviewing the medical records. Table 1 shows the basic characteristics of the selected pts.

\section{Treatment Regimens}

All of the pts received the first-line doublet treatment, chemotherapy regimens include S-1 40-60 mg twice daily on days $1-14$ plus oxaliplatin $130 \mathrm{mg} / \mathrm{m} 2$ on day 1 $(\mathrm{N}=177,71.1 \%)$, the same dose of $\mathrm{S}-1$ plus cisplatin $60 \sim 80 \mathrm{mg} / \mathrm{m} 2$ on day $1(\mathrm{~N}=27,10.8 \%)$, the same dose of S-1 plus paclitaxel $135-175 \mathrm{mg} / \mathrm{m} 2$ on day $1(\mathrm{~N}=13$, $5.2 \%$ ), capecitabine $1000 \mathrm{mg} / \mathrm{m} 2$ twice daily on days $1-14$ plus oxaliplatin $130 \mathrm{mg} / \mathrm{m} 2$ on day $1(\mathrm{~N}=29,11.7 \%)$, docetaxel $75 \mathrm{mg} / \mathrm{m} 2$ on day 1 and cisplatin $75 \mathrm{mg} / \mathrm{m} 2$ on day 1 plus fluorouracil $750 \mathrm{mg} / \mathrm{m} 2 / \mathrm{d}$ on days $1-5$ $(\mathrm{N}=3,1.2 \%)$. The above chemotherapy regimens are all 21 consecutive days per cycle. Treatment was continued

Unresectable locally advanced or metastatic gastric cancer received first-line chemotherapy $(n=397)$

Excluded 148 patients

With other malignancy or single-agent chemotherapy $(n=35)$

Not reach chemotherapy for more than 2 cycles $(n=26)$

Without appropriate effect evaluation data $(n=30)$

Without hemoglobin data $(n=32)$

Without follow-up data(n=25)

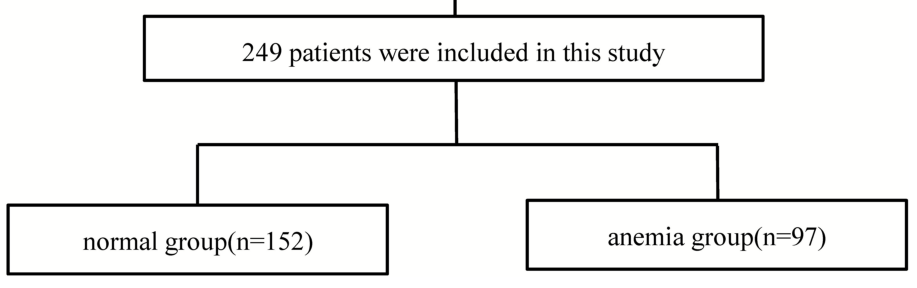

Figure I Flowchart of the patient selection for this study. 
Table I Baseline Information on the 249 Patients with Advanced Gastric Cancer

\begin{tabular}{|c|c|c|c|c|c|}
\hline & $\mathbf{N}$ & $\begin{array}{l}\text { Non- } \\
\text { Anemic } \\
\text { Patients }\end{array}$ & $\begin{array}{l}\text { Anemic } \\
\text { Patients }\end{array}$ & $\chi^{2}$ & $P$ value \\
\hline$N$ & 249 & 152 & 97 & & \\
\hline \multicolumn{6}{|l|}{ Gender } \\
\hline Male & 155 & $94(61.8 \%)$ & $6 \mathrm{I}(62.9 \%)$ & 0.027 & 0.868 \\
\hline Female & 94 & $58(38.2 \%)$ & $36(37.1 \%)$ & & \\
\hline \multicolumn{6}{|l|}{ Age } \\
\hline$<56$ & 115 & $75(49.3 \%)$ & $40(4 \mid .2 \%)$ & 1.565 & 0.211 \\
\hline$\geq 56$ & 134 & $77(50.7 \%)$ & $57(58.8 \%)$ & & \\
\hline \multicolumn{6}{|l|}{ ECOG } \\
\hline $0-1$ & 217 & $143(94.1 \%)$ & $74(76.3 \%)$ & 16.733 & $<0.001$ \\
\hline 2 & 32 & $9(5.9 \%)$ & $23(23.7 \%)$ & & \\
\hline \multicolumn{6}{|l|}{ Site of gastric } \\
\hline Lower & 85 & $44(28.9 \%)$ & $4 I(42.3 \%)$ & 5.379 & 0.146 \\
\hline Upper & 51 & $36(23.7 \%)$ & $15(15.4 \%)$ & & \\
\hline Middle & 86 & $55(36.2 \%)$ & $3 I(32.0 \%)$ & & \\
\hline Others & 27 & $17(11.2 \%)$ & $10(10.3 \%)$ & & \\
\hline \multicolumn{6}{|l|}{$\begin{array}{l}\text { Stage of } \\
\text { differentiation }\end{array}$} \\
\hline High-medium & 45 & $25(16.4 \%)$ & $20(20.6 \%)$ & 1.536 & 0.464 \\
\hline Lower & 130 & $84(55.3 \%)$ & $46(47.4 \%)$ & & \\
\hline Unclear & 74 & $43(28.3 \%)$ & $3 I(32.0 \%)$ & & \\
\hline \multicolumn{6}{|l|}{ Lauren } \\
\hline Diffuse & 122 & 79(52.0\%) & $43(44.3 \%)$ & 2.100 & 0.350 \\
\hline Intestinal & 117 & $66(43.4 \%)$ & $5 \mathrm{I}(52.6 \%)$ & & \\
\hline Mixed & 10 & $7(4.6 \%)$ & $3(3.1 \%)$ & & \\
\hline \multicolumn{6}{|l|}{ Her-2 } \\
\hline Negative & 74 & $45(29.6 \%)$ & $29(29.9 \%)$ & 2.243 & 0.326 \\
\hline Positive & 16 & $7(4.6 \%)$ & $9(9.3 \%)$ & & \\
\hline Unclear & 159 & $100(65.8 \%)$ & $59(60.8 \%)$ & & \\
\hline \multicolumn{6}{|l|}{$\begin{array}{l}\text { Metastatic sites } \\
\text { (Liver) }\end{array}$} \\
\hline Negative & 162 & $102(67.1 \%)$ & $60(61.9 \%)$ & 0.718 & 0.397 \\
\hline Positive & 87 & $50(32.9 \%)$ & $37(38.1 \%)$ & & \\
\hline \multicolumn{6}{|l|}{$\begin{array}{l}\text { Metastatic sites } \\
\text { (lymph nodes) }\end{array}$} \\
\hline Negative & 74 & $51(33.6 \%)$ & $23(23.7 \%)$ & 2.746 & 0.098 \\
\hline Positive & 175 & $101(66.4 \%)$ & $74(76.3 \%)$ & & \\
\hline \multicolumn{6}{|l|}{$\begin{array}{l}\text { Metastatic site } \\
\text { (Ascites) }\end{array}$} \\
\hline Negative & 197 & $118(77.6 \%)$ & $79(81.4 \%)$ & 0.521 & 0.471 \\
\hline Positive & 52 & $34(22.4 \%)$ & $18(18.6 \%)$ & & \\
\hline \multicolumn{6}{|l|}{$\begin{array}{l}\text { Metastatic site } \\
\text { (others) }\end{array}$} \\
\hline Negative & 154 & $96(63.2 \%)$ & $58(59.8 \%)$ & 0.284 & 0.594 \\
\hline Positive & 95 & $56(36.8 \%)$ & $39(40.2 \%)$ & & \\
\hline
\end{tabular}

(Continued)
Table I (Continued).

\begin{tabular}{|c|l|l|l|l|l|}
\hline & N & $\begin{array}{l}\text { Non- } \\
\text { Anemic } \\
\text { Patients }\end{array}$ & $\begin{array}{l}\text { Anemic } \\
\text { Patients }\end{array}$ & $\chi^{2}$ & P value \\
\hline $\begin{array}{l}\text { Initial platelet } \\
\left(10^{9} / \mathrm{L}\right) \\
\leq 80\end{array}$ & 2 & $\begin{array}{l}2(1.3 \%) \\
150(98.7 \%)\end{array}$ & $\begin{array}{l}0(0.0 \%) \\
97(100.0 \%)\end{array}$ & 1.287 & 0.522 \\
$>80$ & 247 & & \\
\hline
\end{tabular}

Abbreviation: ECOG, Eastern Cooperative Oncology Group.

until disease progression, intolerable toxicity, or other reason for termination were judged by the physician.

\section{Assessment}

Evaluation of efficacy after 2 cycles of chemotherapy. Tumor response was evaluated according to Response Evaluation Criteria in Solid Tumors 1.1. The objective response rate (ORR) was defined as the percentage of pts who achieved a CR or PR. Statistical analysis of $\mathrm{Hb}$ levels was performed using baseline $\mathrm{Hb}$ levels before treatment and two cycles after chemotherapy. Anemia was graded according to the National Institute of Cancer Research and Chinese definitions of anemia. Anemia was defined as an $\mathrm{Hb}$ level of $<11.0 \mathrm{~g} / \mathrm{dl}$ in females and $<12.0 \mathrm{~g} / \mathrm{dl}$ in males. ${ }^{12}$ According to the Common Terminology Criteria for Adverse Events (version 4.0), pts were divided into the non-anemia (normal Hb levels) and anemia group. Then, the anemia group was further divided into mild anemia (10 $\mathrm{g} / \mathrm{dl}$ to normal levels), moderate anemia $(8-10 \mathrm{~g} / \mathrm{dl})$, and severe anemia groups $(<8 \mathrm{~g} / \mathrm{dl})$.

Medical records or telephone inquiries were used to measure the duration of survival or confirm death. Progression-free survival (PFS) was defined as the time from diagnosis of metastatic disease to first occurrence of $\mathrm{PD}$, or death. Overall survival (OS) was defined as the time from diagnosis of metastatic disease to death from any cause or the last date of follow-up (June 30, 2019). At the end of follow-up, $236 \mathrm{pts}$ had died.

\section{Statistical Analysis}

Clinicopathological factors were analyzed using Pearson's $\chi^{2}$ or Fisher's exact test. The relationship between $\mathrm{Hb}$ levels and curative effects was examined using Wilcoxon's signedrank test and Mann-Whitney's rank-sum $U$-test. PFS and OS were estimated using the Kaplan-Meier method. Univariate analysis (UVA) and multivariate analysis (MVA) by a Cox proportional hazards regression model 
were used to detect prognostic factors. The statistical significance of survival curves was compared between groups using the Log-rank test. $\mathrm{P}<0.05$ denoted statistical significance in all analyses. All data were analyzed using SPSS 20 statistical software (SPSS Inc., Chicago, IL, USA).

\section{Results}

\section{Clinical Pathology}

Among the 249 pts, 152 (61.0\%) pts had normal Hb levels, whereas 97 (39.0\%) pts had anemia, respectively. Eastern Cooperative Oncology Group performance status of 2 was significantly correlated with anemia $(\mathrm{P}<0.001)$. No differences were observed between pts with and without anemia in terms of gender, age, site of gastric cancer, stage of differentiation, Lauren classification, Her-2 expression, liver metastasis, lymph node metastasis, presence of ascites, and initial platelet counts (Table 1).

Fourteen (5.6\%) pts received red blood cell infusions or erythropoietin treatment, all of whom had severe anemia.

\section{Comparison of $\mathrm{Hb}$ Levels Between Pts with and without Anemia}

The $\mathrm{Hb}$ levels of pts without anemia before and after chemotherapy were $13.35 \pm 1.29$ and $11.93 \pm 1.50 \mathrm{~g} / \mathrm{dl}$, respectively. In order to eliminate the influence of 14 pts treated with blood transfusion or erythropoietin on $\mathrm{Hb}$ changes, we analyzed $\mathrm{Hb}$ levels of 83 anemia pts. The levels among pts with anemia were $9.83 \pm 1.17 \mathrm{~g} / \mathrm{dl}$ before chemotherapy and $10.22 \pm 1.27 \mathrm{~g} / \mathrm{dl}$ after chemotherapy. $\Delta \mathrm{Hb}$ (difference in $\mathrm{Hb}$ levels between before and after chemotherapy) was $-1.42 \pm$ $1.45 \mathrm{~g} / \mathrm{dl}$ among pts without anemia, versus $0.39 \pm 1.39 \mathrm{~g} / \mathrm{dl}$ among pts with anemia $(\mathrm{P}<0.001$, Table 2$)$.

\section{Relationship Between $\mathrm{Hb}$ Levels and Treatment Effects}

Among the 249 pts, CR, PR, SD and PD were recorded in 3 (1.2\%), 109 (43.8\%), 124 (49.8\%), and 13 pts (5.2\%),

Table 2 Comparison of Hemoglobin $(\mathrm{Hb})$ Levels Between Pts with and without Anemia

\begin{tabular}{|c|c|c|c|c|}
\hline & \multirow[t]{2}{*}{$n$} & \multicolumn{3}{|l|}{ Hb (g/dl) } \\
\hline & & $\begin{array}{l}\text { Before } \\
\text { Chemotherapy }\end{array}$ & $\begin{array}{l}\text { After } \\
\text { Chemotherapy }\end{array}$ & $\Delta \mathbf{H b}$ \\
\hline Normal group & 152 & $13.35 \pm 1.29$ & $11.93 \pm 1.50$ & $-1.42 \pm 1.45$ \\
\hline $\begin{array}{l}\text { Anemia group } \\
P \text { value }\end{array}$ & 83 & $9.83 \pm 1.17$ & $10.22 \pm 1.27$ & $\begin{array}{l}0.39 \pm 1.39 \\
<0.001\end{array}$ \\
\hline
\end{tabular}

Table 3 Relationship Between Hemoglobin $(\mathrm{Hb})$ Levels Before Chemotherapy and Treatment Effects

\begin{tabular}{|l|l|l|l|l|l|l|l|}
\hline \multirow{2}{*}{} & \multirow{n}{*}{$\mathbf{n}$} & \multicolumn{4}{|l|}{ Hb } & \multirow{2}{*}{$\chi^{2}$} & \multirow{2}{*}{ P value } \\
\cline { 3 - 6 } & & Normal & Mild & Moderately & Severe & & \\
\hline CR & 3 & 2 & 0 & 1 & 0 & 9.031 & 0.353 \\
PR & 109 & 64 & 22 & 17 & 6 & & \\
SD & 124 & 75 & 20 & 15 & 14 & & \\
PD & 13 & 11 & 0 & 2 & 0 & & \\
\hline
\end{tabular}

respectively. The ORR was $47.4 \%$ (46/97) for pts with anemia, whereas that for pts without anemia was $43.4 \%$ (66/152, $\mathrm{P}=0.536)$. The $\mathrm{Hb}$ level before chemotherapy was not correlated with the treatment effect $(\mathrm{P}=0.353$, Table 3). The $\mathrm{Hb}$ levels before and after chemotherapy in the disease control group $(\mathrm{CR}+\mathrm{PR}+\mathrm{SD})$ were $11.76 \pm 2.39$ and $11.26 \pm 1.67 \mathrm{~g} / \mathrm{dl}$, respectively $(\mathrm{P}<0.001)$, whereas those in the PD group were $12.72 \pm 2.10$ and $10.79 \pm 1.51$ $\mathrm{g} / \mathrm{dl}$, respectively $(\mathrm{P}=0.002)$. $\Delta \mathrm{Hb}$ was $-0.51 \pm 1.86$ in the disease control group, compared with $-1.93 \pm 1.33$ in the PD group $(\mathrm{P}=0.002$, Table 4, Figure 2$)$.

\section{Survival Outcomes}

The median progression-free survival (mPFS) for all pts was 6.3 months ( $95 \%$ confidence interval $[\mathrm{CI}]=6.0-6.6$ ). All patients were divided into four groups, including normal, mild, moderate and severe anemia group, mPFS was 6.3, 7.2, 6.1 and 5.7 months, respectively $(\mathrm{P}=0.121$, Figure $3 \mathrm{~A})$. With $10 \mathrm{~g} / \mathrm{l}$ as the cutoff value, mPFS in patients with non-moderate to severe anemia and moderate to severe anemia was 6.5 and 6.1 months $(\mathrm{P}=0.152$, Figure $3 \mathrm{~B})$. With $8 \mathrm{~g} / 1$ as the cutoff value, the mPFS of pts with severe anemia was 5.7 months, which was significantly shorter than that of pts with non-severe anemia (6.4 months, $\mathrm{P}=0.036$, Figure 3C).

The median overall survival (mOS) of all pts was 14.0 months (95\% CI 12.7-15.3), compared with four groups, including normal, mild, moderate and severe anemia group, mOS was 15.0, 15.9, 11.9 and 10.8 months, respectively

Table 4 Relationship Between the Changes of Hemoglobin $(\mathrm{Hb})$ Levels and Treatment Effects

\begin{tabular}{|l|l|l|l|l|}
\hline \multirow{2}{*}{} & $\mathbf{n}$ & \multicolumn{2}{|l|}{$\mathbf{H b}(\mathbf{g} / \mathbf{d} \mathbf{)}$} & \multirow{2}{*}{ v value } \\
\cline { 3 - 4 } & & $\begin{array}{l}\text { Before } \\
\text { Chemotherapy }\end{array}$ & $\begin{array}{l}\text { After } \\
\text { Chemotherapy }\end{array}$ & \\
\hline $\begin{array}{l}\text { CR+PR+SD } \\
\text { PD }\end{array}$ & 236 & $11.76 \pm 2.39$ & $11.26 \pm 1.67$ & $<0.001$ \\
13 & $12.72 \pm 2.10$ & $10.79 \pm 1.51$ & 0.002 \\
\hline
\end{tabular}




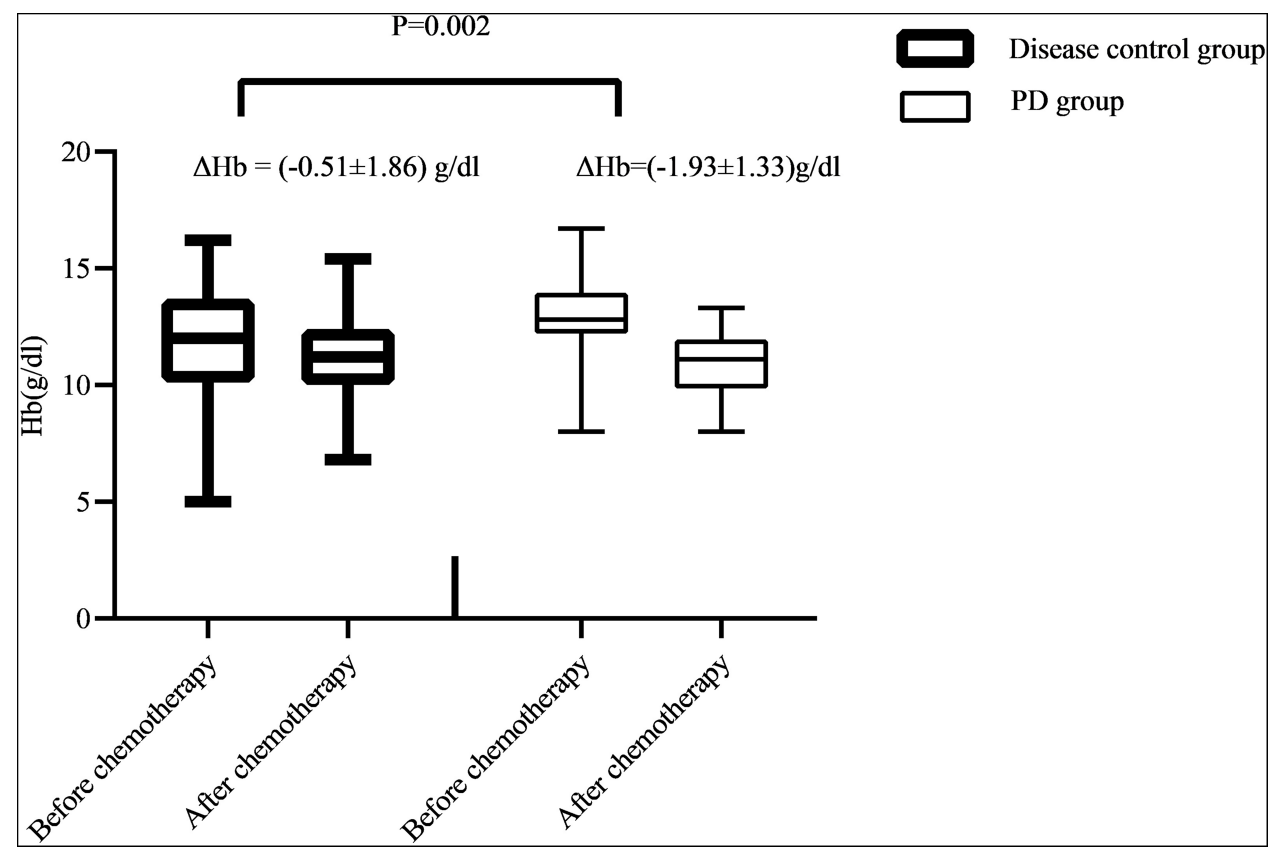

Figure 2 Relationship between the changes of $\mathrm{Hb}$ and treatment effects.

$(\mathrm{P}=0.115$, Figure 3D). The mPFS of pts with moderate or severe anemia was 11.5 months, which was significantly shorter than that of pts with non-moderate to severe anemia (15.0 months, $\mathrm{P}=0.048$, Figure $3 \mathrm{E}$ ). The mOS was 14.6 months for pts with non-severe anemia, versus 10.8 months for pts with severe anemia $(\mathrm{P}=0.104$, Figure $3 \mathrm{~F})$.

Further analysis of our data, 14 of 20 patients with severe anemia received EPO or transfusion therapy, and 6 patients did not receive the treatment. mPFS was 5.9 and 4.6 months $(\mathrm{P}=0.40)$, mOS was 11.0 and 8.9 months $(\mathrm{P}=0.43)$.

\section{Predictors of Mortality}

As for PFS, ascites $(\mathrm{P}=0.028)$ and $\mathrm{Hb}$ post chemotherapy $(\mathrm{P}=0.033)$ were significantly identified in univariate analysis for PFS (Table 5). In multivariate analysis, ascites $(\mathrm{HR}=1.374,95 \% \quad \mathrm{CI}: \quad 1.112 \sim 1.636, \quad \mathrm{P}=0.041) \quad$ and decreased $\mathrm{Hb}$ post chemotherapy $(\mathrm{HR}=1.201,95 \% \mathrm{CI}$ : 1.002 1.400, $\mathrm{P}=0.047$ ) were identified as independent prognostic indicators.

ECOG $(\mathrm{P}=0.008)$, ascites $(\mathrm{P}=0.001)$ and $\mathrm{Hb}$ post chemotherapy $(\mathrm{P}=0.031)$ were significantly identified in univariate analysis for OS (Table 6). In multivariate analysis, ECOG $(\mathrm{HR}=1.253,95 \% \mathrm{CI}: 1.032 \sim 1.522, \mathrm{P}=0.023)$, ascites $(\mathrm{HR}=1.689,95 \% \mathrm{CI}: 1.220 \sim 2.339, \mathrm{P}=0.002)$ and decreased $\mathrm{Hb}$ post chemotherapy $(\mathrm{HR}=1.187,95 \% \mathrm{CI}$ : 1.072 1.302, $\mathrm{P}=0.048$ ) were identified as independent prognostic indicators.

\section{Discussion}

Our single-institution retrospective study analyzed the associations of $\mathrm{Hb}$ levels with treatment outcomes and survival in 249 pts with AGC who received first-line chemotherapy. Our research demonstrated that $\mathrm{Hb}$ levels are associated with prognosis. Pts with PD experience a larger decrease in $\mathrm{Hb}$ levels, and those with low $\mathrm{Hb}$ levels have a poor prognosis.

The results illustrated that a poor performance status was significantly correlated with anemia, which is consistent with the results of other studies. ${ }^{13,14}$ This research demonstrated that $\mathrm{Hb}$ levels tended to decrease after treatment in pts without anemia, versus an upward trend in pts with anemia. This finding might be related to adverse reactions to chemotherapy in pts with normal baseline levels of Hb. ${ }^{15}$ In such pts, the drug damages hematopoietic stem cells and causes anemia. Chemotherapy can also damage the kidneys, thereby decreasing the secretion of erythropoietin and inducing anemia. ${ }^{16}$ Meanwhile, among pts without anemia, the tumor inhibits hematopoietic function through the direct invasion of bone marrow. The size of the lesion is reduced by chemotherapy, resulting in improved hematopoietic function and increased $\mathrm{Hb}$ levels.

In our study, the ORR of first-line chemotherapy in pts with AGC was $45 \%$, in line with those in the Real-2 study $(46.4 \%)^{17}$ and SPIRITS trial $(31-54 \%) .^{18}$ There are few reports on the relationship of changes in $\mathrm{Hb}$ levels 
A

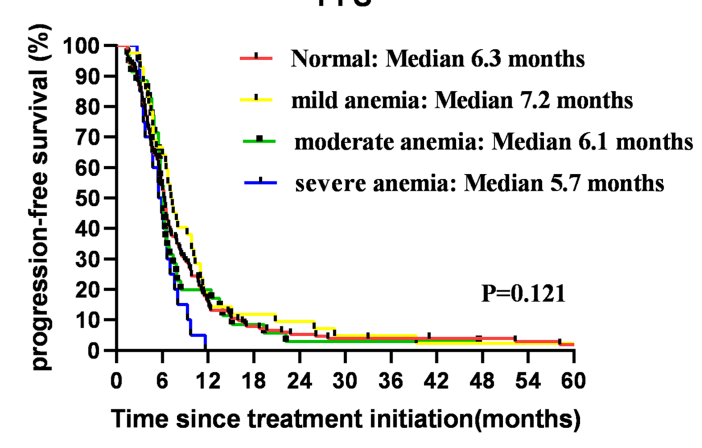

B

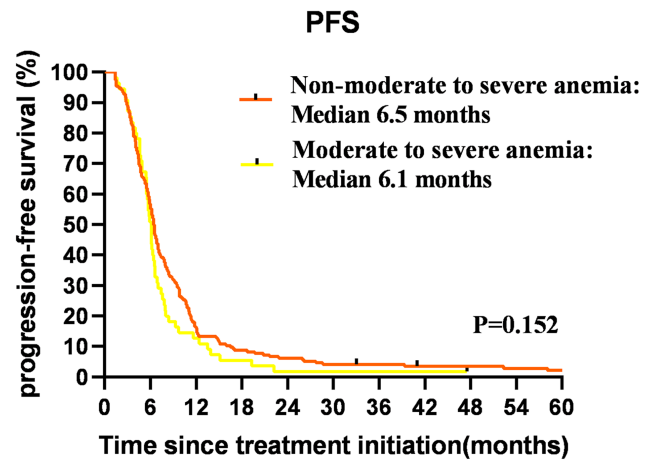

C

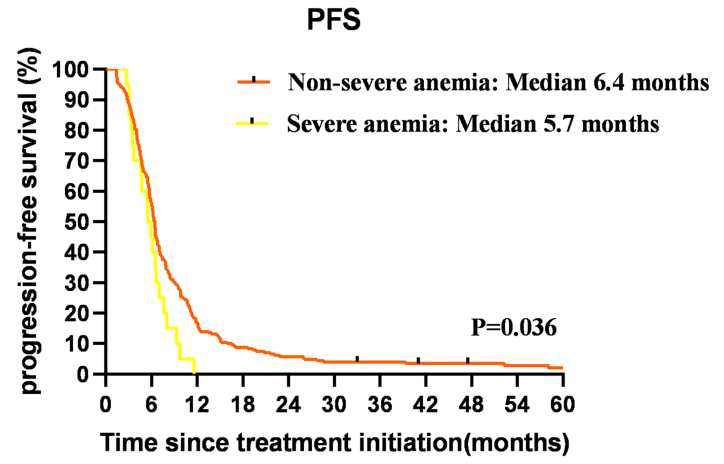

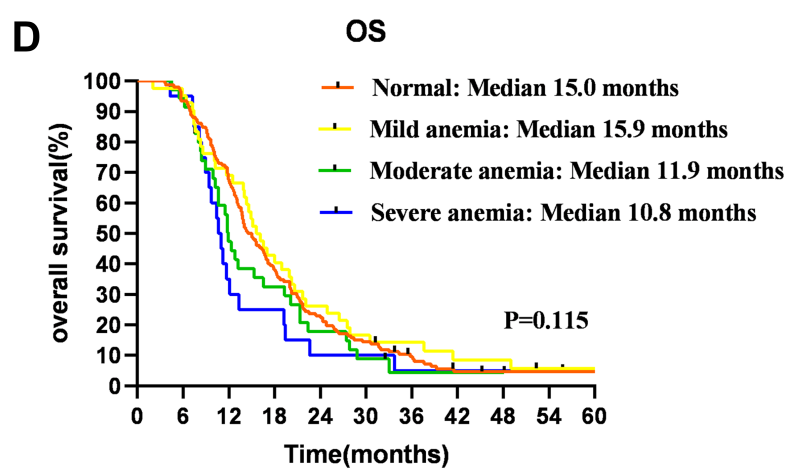

E os

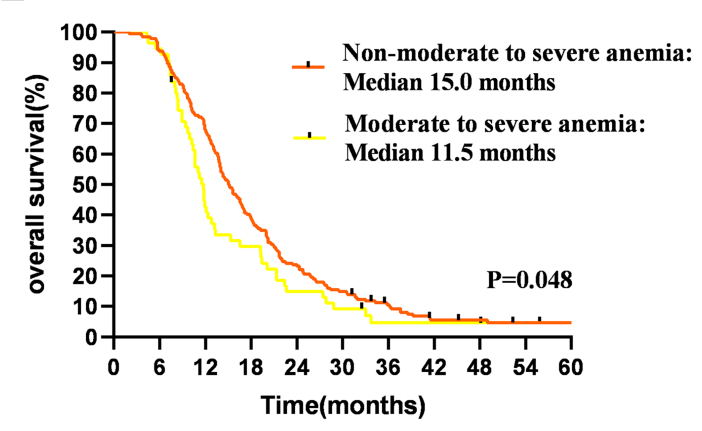

$\mathbf{F}$ os

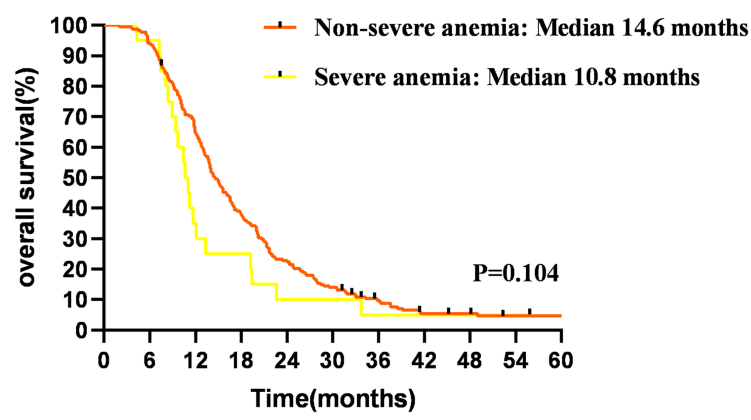

Figure 3 Progression-free survival and overall survival of all patients. (A) Kaplan-Meier (KM) survival curves comparing the PFS of patients with normal, mild, moderate and severe anemia group.(B) Comparing the PFS of patients with non-moderate to severe anemia and moderate to severe anemia group. (C) Comparing the PFS of patients with non-severe anemia and severe anemia group. (D) Comparing the OS of patients with normal, mild, moderate and severe anemia group. (E) Comparing the OS of patients with non-moderate to severe anemia and moderate to severe anemia group. (F) Comparing the OS of patients with non-severe anemia and severe anemia group.

Abbreviations: PFS, progression-free survival; OS, overall survival.

between before and after chemotherapy with efficacy in pts with AGC. Our results illustrated that $\mathrm{Hb}$ levels decreased in both the disease control and PD groups. Compared with the findings in the disease control group, $\mathrm{Hb}$ levels were significantly decreased in the PD group after treatment. This may be attributed to hypoxic supply of tumor tissue influencing the efficacy of chemotherapy. ${ }^{19}$
This result suggests that changes in $\mathrm{Hb}$ levels between before and after chemotherapy can predict treatment efficacy.

The relationship between anemia and treatment outcomes has been described by several authors. Park et $\mathrm{al}^{8}$ reported that pts with baseline $\mathrm{Hb}$ levels $<10 \mathrm{~g} / \mathrm{dl}$ had lower response rates and higher risks of death. $\mathrm{Ji}$ et $\mathrm{al}^{20}$ 
Table 5 Univariate and Multivariate Analysis for PFS

\begin{tabular}{|c|c|c|c|c|c|}
\hline \multirow[t]{2}{*}{ Variate } & \multirow[t]{2}{*}{$\mathbf{N}$} & \multicolumn{2}{|l|}{ Univariate } & \multicolumn{2}{|l|}{ Multivariate } \\
\hline & & HR & $\mathbf{P}$ & HR & $\mathbf{P}$ \\
\hline Gender & & & 0.668 & & \\
\hline Male & 155 & Reference & & & \\
\hline Female & 94 & $0.944(0.725 \sim 1.229)$ & & & \\
\hline Age & & & 0.564 & & \\
\hline$<56$ & 115 & Reference & & & \\
\hline$\geq 56$ & 134 & 0.927 (0.717 1.199) & & & \\
\hline ECOG & & & 0.065 & & \\
\hline $0-1$ & 217 & Reference & & & \\
\hline 2 & 32 & $1.433(0.978 \sim 2.100)$ & & & \\
\hline Site of gastric & & & 0.743 & & \\
\hline Lower & 85 & Reference & & & \\
\hline Upper & 51 & $0.389(0.07 \sim 2.156)$ & & & \\
\hline Middle & 86 & $0.979(0.184 \sim 5.209)$ & & & \\
\hline Others & 27 & $0.732(0.152 \sim 3.522)$ & & & \\
\hline Stage of differentiation & & & 0.767 & & \\
\hline High-medium & 45 & Reference & & & \\
\hline Lower & 130 & I.III (0.785 I.574) & & & \\
\hline Unclear & 74 & I. 149 (0.785 1.682) & & & \\
\hline Lauren classification & & & 0.313 & & \\
\hline Diffuse & 122 & Reference & & & \\
\hline Intestinal & 117 & $0.860(0.662 \sim 1.118)$ & & & \\
\hline Mixed & 10 & $\mathrm{I} .299(0.680 \sim 2.48 \mathrm{I})$ & & & \\
\hline Her-2 & & & 0.412 & & \\
\hline Negative & 74 & Reference & & & \\
\hline Positive & 16 & $1.334(0.142 \sim 12.496)$ & & & \\
\hline Unclear & 159 & $0.449(0.120 \sim 1.680)$ & & & \\
\hline Metastatic sites (Liver) & & & 0.228 & & \\
\hline Negative & 162 & Reference & & & \\
\hline Positive & 87 & I.I79 (0.902 I.54I) & & & \\
\hline Metastatic sites (lymph nodes) & & & 0.456 & & \\
\hline Negative & 74 & Reference & & & \\
\hline Positive & 175 & $0.899(0.680 \sim 1.189)$ & & & \\
\hline Metastatic site (Ascites) & & & 0.028 & & 0.041 \\
\hline Negative & 197 & Reference & & Reference & \\
\hline Positive & 52 & 1.421 (I.145 1.697) & & $1.374(1.112 \sim 1.636)$ & \\
\hline Metastatic site (others) & & & 0.458 & & \\
\hline Negative & 154 & Reference & & & \\
\hline Positive & 95 & $0.905(0.695 \sim 1.179)$ & & & \\
\hline Anemia & & & 0.21 & & \\
\hline Normal & 152 & Reference & & & \\
\hline Mild & 42 & $0.837(0.589 \sim 1.188)$ & & & \\
\hline Moderate & 35 & $1.033(0.707 \sim 1.510)$ & & & \\
\hline Severe & 20 & I.52I (0.937 2.468) & & & \\
\hline
\end{tabular}

(Continued) 
Table 5 (Continued).

\begin{tabular}{|l|l|l|l|l|l|}
\hline \multirow{2}{*}{ Variate } & N & Univariate & \multicolumn{2}{l|}{ Multivariate } \\
\cline { 2 - 6 } & & HR & P & HR \\
\hline $\begin{array}{l}\text { Hb post chemotherapy } \\
\text { Elevated } \\
\text { Decreased }\end{array}$ & 85 & $\begin{array}{l}\text { Reference } \\
1.224(I .017 \sim 1.43 \mathrm{I})\end{array}$ & 0.033 & & Reference \\
& 164 & & 0.047 \\
\hline
\end{tabular}

Abbreviation: ECOG, Eastern Cooperative Oncology Group.

Table 6 Univariate and Multivariate Analysis for OS

\begin{tabular}{|c|c|c|c|c|c|}
\hline \multirow[t]{2}{*}{ Variate } & \multirow[t]{2}{*}{$\mathbf{N}$} & \multicolumn{2}{|l|}{ Univariate } & \multicolumn{2}{|l|}{ Multivariate } \\
\hline & & HR & $\mathbf{P}$ & HR & $\mathbf{P}$ \\
\hline Gender & & & 0.578 & & \\
\hline Male & 155 & Reference & & & \\
\hline Female & 94 & $0.927(0.7 \mid I \sim 1.209)$ & & & \\
\hline Age & & & 0.604 & & \\
\hline$<56$ & 115 & Reference & & & \\
\hline$\geq 56$ & 134 & $0.934(0.723 \sim 1.207)$ & & & \\
\hline ECOG & & & 0.008 & & 0.023 \\
\hline $0-1$ & 217 & Reference & & Reference & \\
\hline 2 & 32 & $1.739(1.188 \sim 2.546)$ & & I.253 (I.032 1.522) & \\
\hline Site of gastric & & & 0.259 & & \\
\hline Lower & 85 & & & & \\
\hline Upper & 51 & I.073 (0.789 I.459) & & & \\
\hline Middle & 86 & $0.859(0.602 \sim 1.225)$ & & & \\
\hline Others & 27 & 0.697 (0.434 1.I 19) & & & \\
\hline Stage of differentiation & & & 0.438 & & \\
\hline High-medium & 45 & Reference & & & \\
\hline Lower & 130 & I. 197 (0845 I.696) & & & \\
\hline Unclear & 74 & I.279 (0.874 I.87I) & & & \\
\hline Lauren classification & & & 0.211 & & \\
\hline Diffuse & 122 & Reference & & & \\
\hline Intestinal & 117 & $0.823(0.633 \sim 1.069)$ & & & \\
\hline Mixed & 10 & $\mathrm{I} .255(0.656 \sim 2.40 \mathrm{I})$ & & & \\
\hline Her-2 & & & 0.281 & & \\
\hline Negative & 74 & Reference & & & \\
\hline Positive & 16 & $0.648(0.370 \sim 1.134)$ & & & \\
\hline Unclear & 159 & $0.988(0.743 \sim 1.314)$ & & & \\
\hline Metastatic sites (Liver) & & & 0.575 & & \\
\hline Negative & 162 & Reference & & & \\
\hline Positive & 87 & $\mathrm{I} .080(0.826 \sim \mathrm{I} .4 \mathrm{II})$ & & & \\
\hline Metastatic sites (lymph nodes) & & & 0.775 & & \\
\hline Negative & 74 & Reference & & & \\
\hline Positive & 175 & $1.042(0.788 \sim 1.378)$ & & & \\
\hline
\end{tabular}

(Continued) 
Table 6 (Continued).

\begin{tabular}{|c|c|c|c|c|c|}
\hline \multirow[t]{2}{*}{ Variate } & \multirow[t]{2}{*}{$\mathbf{N}$} & \multicolumn{2}{|l|}{ Univariate } & \multicolumn{2}{|l|}{ Multivariate } \\
\hline & & HR & $\mathbf{P}$ & HR & $\mathbf{P}$ \\
\hline Metastatic site (Ascites) & & & 0.001 & & 0.002 \\
\hline Negative & 197 & Reference & & Reference & \\
\hline Positive & 52 & 1.791 (1.300 2.466) & & 1.689 (I.220 2.339) & \\
\hline Metastatic site (others) & & & 0.22 & & \\
\hline Negative & 154 & Reference & & & \\
\hline Positive & 95 & $0.847(0.650 \sim 1.104)$ & & & \\
\hline Anemia & & & 0.252 & & \\
\hline Normal & 152 & Reference & & & \\
\hline Mild & 42 & $0.925(0.65 \mid \sim 1.313)$ & & & \\
\hline Moderate & 35 & $1.274(0.872 \sim 1.861)$ & & & \\
\hline Severe & 20 & $1.473(0.9 \mid \mathrm{I} \sim 2.380)$ & & & \\
\hline $\mathrm{Hb}$ post chemotherapy & & & 0.031 & & 0.048 \\
\hline Elevated & 85 & Reference & & Reference & \\
\hline Decreased & 164 & $1.274(1.012 \sim 1.536)$ & & I.187 (1.072 1.302) & \\
\hline
\end{tabular}

Abbreviation: ECOG, Eastern Cooperative Oncology Group.

found that low baseline $\mathrm{Hb}$ levels represented an independent negative prognostic factor for OS. However, no correlation between anemia and survival was noted in other studies. ${ }^{10,11}$ In terms of ORRs, our study identified no obvious difference between pts with and without anemia. This finding may be related to regional and racial differences and different definitions of anemia. In our study, the median PFS was prolonged in pts with non-severe anemia $(\mathrm{Hb} \geq 8 \mathrm{~g} / \mathrm{dl})$ compared with severe anemia. Meanwhile, median OS was prolonged in pts with non-anemia and mild anemia $(\mathrm{Hb} \geq 10 \mathrm{~g} / \mathrm{dl})$ compared with moderate or severe anemia. American Society of Clinical Oncology and American Society of Hematology guidelines ${ }^{21}$ recommended starting anemia treatment when $\mathrm{Hb}$ levels are less than $10 \mathrm{~g} / \mathrm{dl}$. Our findings suggest that OS and PFS tend to prolong after correcting severe anemia, also numerous reports have demonstrated that correcting anemia can improve patient outcomes, ${ }^{22,23}$ effective management of anemia is important for treating gastric cancer. ${ }^{24}$

The relationship between low baseline $\mathrm{Hb}$ levels and poor prognosis in pts with AGC may be attributable to several factors. Anemia reduces oxygen-carrying capacity of the blood, which leads to hypoxia. ${ }^{25}$ Hypoxia can stimulate angiogenesis, which increases tumor aggressiveness. ${ }^{26,27}$ Additionally, tumor cells can secrete interleukin-6 and tumor necrosis factor- $\alpha$, which change the hematopoietic microenvironment and lead to decreases in $\mathrm{Hb}$ concentrations. $^{28,29}$ Hypoxia can accelerate malignant tumor progression and tumor metastasis through various mechanisms, such as tumor suppressor gene inactivation, changes in gene expression, and clonal selection, thereby increasing resistance to chemotherapy ${ }^{30}$ and ultimately resulting in poor long-term outcomes.

Our study is the largest retrospective study of analyzing the relationship between changes in Hb levels and the efficacy of first-line chemotherapy in patients with advanced gastric cancer. This paper not only analyzes the relationship between baseline hemoglobin and objective response rate, but also discuss the correlation between hemoglobin changes and efficacy. Second, the research demonstrates the correlation between different levels of anemia and survival. However, our study had several limitations. First, this report was a single-center retrospective study with a limited sample size and possible incomplete information, resulting in recall bias. Second, it is difficult to rule out the effects of chemotherapy when assessing the correlation between $\mathrm{Hb}$ levels and efficacy. Furthermore, some information relevant to anemia such as iron and vitamin B12 levels were not available, preventing a deeper analysis of pts with anemia. To resolve these problems, prospective research is needed in the future.

\section{Conclusions}

Our study found that low baseline Hb levels signify a poor prognosis in pts with advanced gastric cancer. Pts with baseline $\mathrm{Hb}$ levels $\geq 10 \mathrm{~g} / \mathrm{dl}$ have longer OS. Additionally, pts with disease progression experience larger decreases in 
$\mathrm{Hb}$ level, and the degree of change in $\mathrm{Hb}$ levels might be a biomarker for predicting efficacy. Larger samples and more complete data are needed to assess whether early intervention for anemia in pts with advanced gastric cancer can improve prognosis.

\section{Acknowledgment}

This research was supported by Zhejiang Science Technology Plan Project (No.2017C37138).

\section{Disclosure}

The authors report no conflicts of interest in this work.

\section{References}

1. Ferlay J, Soerjomataram I, Dikshit R, et al. Cancer incidence and mortality worldwide: sources, methods and major patterns in GLOBOCAN 2012. Int $J$ Cancer. 2015;136(5):E359-E386. doi:10.1002/ijc. 29210

2. Catalano V, Labianca R, Beretta GD, Gatta G, de Braud F, Van Cutsem E. Gastric cancer. Crit Rev Oncol Hematol. 2009;71 (2):127-164. doi:10.1016/j.critrevonc.2009.01.004

3. Groopman JE, Itri LM. Chemotherapy-induced anemia in adults: incidence and treatment. $J$ Natl Cancer Inst. 1999;91 (19):1616-1634. doi:10.1093/jnci/91.19.1616

4. Gilreath JA, Stenehjem DD, Rodgers GM. Diagnosis and treatment of cancer-related anemia. Am J Hematol. 2014;89(2):203-212. doi:10.1002/ajh.23628

5. Schwartz RN. Anemia in patients with cancer: incidence, causes, impact, management, and use of treatment guidelines and protocols. Am J Health Syst Pharm. 2007;64(3 Suppl 2):S5-S30. doi:10.2146/ajhp060601

6. Wilson J, Yao GL, Raftery J, et al. A systematic review and economic evaluation of epoetin alpha, epoetin beta and darbepoetin alpha in anaemia associated with cancer, especially that attributable to cancer treatment. Health Technol Assess. 2007;11(13):1-iv. doi:10.3310/hta11130

7. Leger RM, Jain S, Nester TA, Kaplan H. Drug-induced immune hemolytic anemia associated with anti-carboplatin and the first example of anti-paclitaxel. Transfusion. 2015;55(12):2949-2954. doi:10.1111/ trf. 13255

8. Park SH, Lee J, Lee SH, et al. Anemia is the strongest prognostic factor for outcomes of 5-fluorouracil-based first-line chemotherapy in patients with advanced gastric cancer. Cancer Chemother Pharmacol. 2006;57(1):91-96. doi:10.1007/s00280-005-0027-2

9. Mohri Y, Tanaka K, Ohi M, Yokoe T, Miki C, Kusunoki M. Prognostic significance of host- and tumor-related factors in patients with gastric cancer. World J Surg. 2010;34(2):285-290. doi:10.1007/ s00268-009-0302-1

10. Lee J, Lim T, Uhm JE, et al. Prognostic model to predict survival following first-line chemotherapy in patients with metastatic gastric adenocarcinoma. Ann Oncol. 2007;18(5):886-891. doi:10.1093/ annonc/mdl501

11. Zhu X, Zhao X, Peng W, et al. Epirubicin combined with oxaliplatin and 5-day continuous infusion of 5-fluorouracil as a first-line treatment for metastatic gastric cancer: treatment outcomes and analysis of prognostic factors. J Cancer Res Clin Oncol. 2015;141 (1):109-118. doi:10.1007/s00432-014-1754-8

12. Experts Committee on Cancer -Related Anemia; Chinese Society of Clinical Oncology (CSCO). Clinical practice guidelines on cancerrelated anemia (2012-2013 edition). Chin Clin Oncol. 2012;1(2):18. doi:10.3978/j.issn.2304-3865.2012.10.01
13. Ludwig H, Van Belle S, Barrett-Lee P, et al. The European Cancer Anaemia Survey (ECAS): a large, multinational, prospective survey defining the prevalence, incidence, and treatment of anaemia in cancer patients. Eur J Cancer. 2004;40(15):2293-2306. doi:10.1016/j.ejca.2004.06.019

14. Ludwig H, Strasser K. Symptomatology of anemia. Semin Oncol. 2001;28(2 Suppl 8):7-14. doi:10.1016/s0093-7754(01)90206-4

15. Park MH, Baek B, Jin HK, Bae J-S. Novel peptides derived from neuropeptide $\mathrm{Y}$ prevent chemotherapy-induced bone marrow damage by regulating hematopoietic stem cell microenvironment. Anim Cells Syst. 2018;22(5):281-288. doi:10.1080/19768354.2018.1517826

16. Testa U, Castelli G, Elvira P. Experimental and investigational therapies for chemotherapy-induced anemia. Expert Opin Investig Drugs. 2015;24(11):1433-1445. doi:10.1517/13543784.2015.1085505

17. Cunningham D, Starling N, Rao S, et al. Capecitabine and oxaliplatin for advanced esophagogastric cancer. $N$ Engl J Med. 2008;358 (1):36-46. doi:10.1056/NEJMoa073149

18. Koizumi W, Narahara H, Hara T, et al. S-1 plus cisplatin versus S-1 alone for first-line treatment of advanced gastric cancer (SPIRITS trial): a Phase III trial. Lancet Oncol. 2008;9(3):215-221. doi:10.1016/S1470-2045(08)70035-4

19. Vaupel P, Kelleher DK, Höckel M. Oxygen status of malignant tumors: pathogenesis of hypoxia and significance for tumor therapy. Semin Oncol. 2001;28(2 Suppl 8):29-35. doi:10.1016/s00937754(01)90210-6

20. Ji SH, Lim DH, Yi SY, et al. A retrospective analysis of second-line chemotherapy in patients with advanced gastric cancer. BMC Cancer. 2009;9(1):110. doi:10.1186/1471-2407-9-110

21. Bohlius J, Bohlke K, Castelli R, et al. Management of cancer-associated anemia with erythropoiesis-stimulating agents: ASCO/ASH clinical practice guideline update. Blood Adv. 2019;3 (8):1197-1210. doi:10.1182/bloodadvances.2018030387

22. Littlewood TJ, Bajetta E, Nortier JW, Vercammen E, Rapoport B, Epoetin Alfa Study Group. Effects of epoetin alfa on hematologic parameters and quality of life in cancer patients receiving nonplatinum chemotherapy: results of a randomized, double-blind, placebo-controlled trial. J Clin Oncol. 2001;19(11):2865-2874. doi:10.1200/JCO.2001.19.11.2865

23. Glaser CM, Millesi W, Kornek GV, et al. Impact of hemoglobin level and use of recombinant erythropoietin on efficacy of preoperative chemoradiation therapy for squamous cell carcinoma of the oral cavity and oropharynx. Int J Radiat Oncol Biol Phys. 2001;50 (3):705-715. doi:10.1016/s0360-3016(01)01488-2

24. Henry DH. Guidelines for the use of epoetin in cancer patients: a much-needed step forward in standardizing anemia treatment. Blood. 2003;102(7):2697-2698. doi:10.1182/blood-2003-02-0427

25. Vaupel P, Thews O, Hoeckel M. Treatment resistance of solid tumors: role of hypoxia and anemia. Med Oncol. 2001;18(4):243-259. doi:10.1385/MO:18:4:243

26. Knight K, Wade S, Balducci L. Prevalence and outcomes of anemia in cancer: a systematic review of the literature. Am J Med. 2004;116 (Suppl 7A):11S-26S. doi:10.1016/j.amjmed.2003.12.008

27. Tilan J, Czarnecka M, Kitlinska J. Sympathetic signaling in angiogenesis: implications for cancer progression. Curr Cancer Ther Rev. 2012;8(2):83-89. doi:10.2174/157339412800675333

28. Banzet S, Sanchez H, Chapot R, Bigard X, Vaulont S, Koulmann N. Interleukin- 6 contributes to hepcidin mRNA increase in response to exercise. Cytokine. 2012;58(2):158-161. doi:10.1016/j.cyto.2012.01.006

29. Sun CC, Vaja V, Babitt JL, Lin HY. Targeting the hepcidin-ferroportin axis to develop new treatment strategies for anemia of chronic disease and anemia of inflammation. $\mathrm{Am}$ J Hematol. 2012;87(4):392-400. doi:10.1002/ajh.23110

30. Vaupel P. The role of hypoxia-induced factors in tumor progression. Oncologist. 2004;9(Suppl 5):10-17. doi:10.1634/theoncologist.9-90 005-10 


\section{Publish your work in this journal}

Cancer Management and Research is an international, peer-reviewed open access journal focusing on cancer research and the optimal use of preventative and integrated treatment interventions to achieve improved outcomes, enhanced survival and quality of life for the cancer patient.

Submit your manuscript here: https://www.dovepress.com/cancer-management-and-research-journa
The manuscript management system is completely online and includes a very quick and fair peer-review system, which is all easy to use. Visit http://www.dovepress.com/testimonials.php to read real quotes from published authors. 